\title{
The role of thrombophilia genes in the clinical implementation of arterial and venous thrombosis in newborns
}

\author{
O. A. Filippova ${ }^{1 *}, I . V$. Vakhlova $^{1}, G . A$. Tsaur $^{1,2}, N . N$. Kuznetsov $^{1}$, and T. B. Abolina ${ }^{1}$ \\ ${ }^{1}$ Ural State Medical University, Yekaterinburg, 3, Repina st., Yekaterinburg, 620028, Russia \\ ${ }^{2}$ Regional children's clinical hospital, Yekaterinburg, Russia
}

\begin{abstract}
The article considers the analysis results of the occurrence frequency of genotypes and alleles of plasma, platelet and fibrinolytic hemostasis in full-term newborns with arterial and venous thrombosis of various localization. Gene polymorphisms were studied by real-time PCR in human DNA samples obtained from buccal epithelium and venous blood lymphocytes. The control group was a group of healthy full-term newborns from families without a thrombophilic history. Predictors of arterial and venous thrombosis in children are such as polymorphism of the plasminogen activator inhibitor gene PAI-1-675 4G/4G (OR=5,6 [2,3$13,8]$ ), combinations of polymorphisms PAI-1-675 4G/4G + factor VII G10976A G/G (OR=5,8 [1,7-19,1]), combinations of polymorphisms PAI-1 -675 4G/4G + factor VII G10976A G/G + factor XIII Val34Leu G/G (\% AR=61), fibrinogen FGB -455 G/A $(\mathrm{OR}=3,75[1,4-9,4])$ and integrin alpha 2 ITGA2 $807 \mathrm{~T} / \mathrm{T}(\mathrm{OR}=15,56[1,9-126,7])$. Thus, the study of polymorphisms of the plasminogen activator inhibitor, fibrinogen, integrin alpha 2 can serve as one of the criteria for identifying a high-risk group for the development of arterial and venous thrombosis in newborns and should be taken into account when evaluating individual thrombophilia risk.
\end{abstract}

\section{Introduction}

The observed increase in venous and arterial thrombosis in newborns is associated with advances and new technologies used in obstetrics and neonatology [1, 2]. Thrombotic complications in various diseases are observed in 5.3 patients per 10,000 children hospitalized during the year [3]. According to the published USA data, a sharp increase in the occurrence of venous thrombosis in children - up to 188 per 100,000 discharged children - was shown [4,5]. To date, only the results of single studies of thrombosis risk associated with hereditary thrombophilia have been published [6-9]. It is commonly known that the hemostasis system is involved in many physiological and pathophysiological processes, including processes related to the course of neonatal adaptation. The development of arterial and venous thrombosis in newborns has a multifactor cause and can be realized in both perinatal and late neonatal periods. Exogenic factors of thrombogenic risk are such as congenital heart defects, intrauterine infections, early neonatal sepsis,

\footnotetext{
*Corresponding author: glesenok@yandex.ru
} 
severe asphyxia, neonatal hypotrophy [10]. Successes in studying such a fundamental component of endogenous risk of thrombotic "catastrophes" development as a genetic predisposition determine an important place in thrombosis pathogenesis of hereditary thrombophilia $[11,12,13,14,15]$. There is currently a scientific debate on the role of thrombophilia in the thrombosis development in children. Meta-analyses indicate that thrombophilia is a risk factor for arterial and venous thrombosis [16, 17].

The purpose of this study was to evaluate the role of polymorphisms of genes of plasma, platelet, fibrinolytic hemostasis in the development of thrombosis in newborn children.

\section{Materials and Methods}

An observational study on the "case-control" type was conducted. The main group of observation was 46 full-term newborns with arterial and venous thrombosis of different localization. The control group was 57 newborn children of health groups I and II. The main and control groups were comparable in gender and anthropometric rates at birth. In the main group, boys were $65.2 \%(n=30)$, girls - $34.8 \%(n=16)$, in the control group - 56\% $(n=32)$ and $44 \%(n=25)$ respectively. Children's weight at birth in the main group was $3322.55 \pm 414.57 \mathrm{~g}$., average body length was $50.9 \pm 1.2 \mathrm{~cm}$; in children of the control group - 3340, $0 \pm 321.10 \mathrm{~g}$ and $51.5 \pm 1.2 \mathrm{~cm}$ respectively.

Criteria for inclusion in the main group were: age of 28 days and less, full-term birth (gestational period more than 37 weeks), diagnosed thrombosis in the arterial and/or venous system, presence of informed voluntary consent of the child's legal representative to participate in the study. Criteria for exclusion were: age 29 days and up, gestational period of 37 or less weeks, congenital thrombophilia due to deficiency of physiological anticoagulants - antithrombin, protein $\mathrm{C}$ and protein $\mathrm{S}$. The criterion for inclusion in the control group was health group I or II; the criteria for exclusion were: indications in maternal history of a burdened thrombophilic history, type I diabetes; immunodeficiency conditions, systemic diseases, oncological diseases, arterial and venous thromboses of different localization.

Children of the main group were subject to instrumental visualization of clot localization: ultrasound vessels diagnostics (Philips IE 33, Netherlands), computerized tomography (Philips Aquilion 64, Netherlands), magnetic resonance imaging (Philips Achieva 1,5T, Netherlands).

In order to exclude congenital thrombophilia due to the deficiency of physiological anticoagulants - antithrombin, protein $\mathrm{C}$ and protein $\mathrm{S}$, a study of fibrinogen concentration activated partial thromboplastin time, thrombin time, antithrombin, D-dimers, protein $\mathrm{C}$ and protein $\mathrm{S}$, homocysteine concentration.

Molecular genetic study of thrombophilia genes polymorphisms was conducted in the Laboratory of Molecular Biology, Immunophenotyping and Pathomorphology of the Regional Children's Clinical Hospital (Yekaterinburg). Genetic polymorphisms were determined by real-time polymerase chain reaction (PCR-RT) in DNA preparations isolated from defrosted whole blood samples using a set "PROBA-RAPID-GENETICS" ("NGO DNK-Technologiya", Russia). The obtained DNA was used as initial material for carrying out PCR-RT using the set "CardioGenetics Thrombophilia" ("NGO DNA Technology") on the detecting amplifier DTprime 5M1 ( "NGO DNA Technology") followed by automatic analysis of the data obtained using RealTime_PCR software ("NGO DNA Technology"). The "Cardiogenetics Thrombophilia" set includes 8 single-nucleotide polymorphisms: $F G B-455 \mathrm{G}>\mathrm{A}(\mathrm{rs} 1800790), F 220210 \mathrm{G}>\mathrm{A}(\mathrm{rs} 1799963), F 51691 \mathrm{G}>\mathrm{A}$ (rs6025), F7 10976 $\mathrm{G}>\mathrm{A}$ (rs6046), F13 G>T (rs5985), ITGA2 $807 \mathrm{C}>\mathrm{T}$ (rs1126643), ITGB3 $1565 \mathrm{~T}>\mathrm{C}$ (rs5918), PAI-1-675 5G>4G (rs1799889). 
Statistical analysis was performed using the Statistica application package 10.0 for Windows. The frequency of cases (n), frequency ratio of cases $(\%)$ were calculated. The differences significance in observational frequencies in the compared groups was assessed using the criteria $\chi 2$ at $\mathrm{p} \leq 0.050$. Connection analysis was performed using associative indicators - attribute risk ( $\mathrm{AR}, \%$ ), odds ratio (OR), relative risk (RR) with $95 \%$ confidence interval calculation. Attributive contribution, or percentage of attributive risk $(\% \mathrm{AR})$ was calculated by the formula $\% \mathrm{AR}=[(\mathrm{RR}-1) / \mathrm{RR}] \times 100 \%$ applicable for casecontrol studies [18].

\section{Results and Discussion}

During clinical laboratory and instrumental imaging, arterial and venous thrombosis were detected in the children of the main group. Among arterial thrombosis the most common was ischemic stroke in the middle cerebral artery circulation (predominantly on the left) - in 37\% of cases; sinus thrombosis prevailed among venous thrombosis - in 30\% of cases. The ratio of arterial thrombosis to venous was 1.5:1 (table 1).

Table 1. Frequency and localization of arterial and venous thrombosis in children of the main group

\begin{tabular}{|c|c|c|c|}
\hline \multicolumn{2}{|c|}{ Arterial thromboses, $\mathrm{n}=28$} & \multicolumn{2}{c|}{ Venous thromboses, $\mathrm{n}=18$} \\
\hline & $\mathrm{n}(\%)$ & $\mathrm{n}(\%)$ \\
\hline Ischemic stroke in the MCA circulation & $17(37)$ & Sinus thrombosis & $14(30.4)$ \\
\hline Abdominal aorta & $3(6.5)$ & Limb veins & $4(8.7)$ \\
\hline Limb arteries & $4(8.7)$ & & \\
\hline Testicular artery & $3(6.5)$ & & \\
\hline Splenic artery & $1(2.1)$ & & \\
\hline
\end{tabular}

Molecular genetic study of gene polymorphisms of plasma, platelet, fibrinolytic links of the hemostasis system established the following differences between children of the main and control groups (Table 2):

- shown a reliably higher occurrence frequency of fibrinogen polymorphism FGB -455 G/A, as well as sums of FGB $-455 \mathrm{G} / \mathrm{A}+\mathrm{FGB}-455 \mathrm{~A} / \mathrm{A}$ in children of the main group $(\mathrm{p} \leq$ 0.02 and $\mathrm{p} \leq 0.004$ respectively); more high frequency of FGB $-455 \mathrm{G} / \mathrm{G}$ polymorphism in control group children $(\mathrm{p} \leq 0.004)$;

- revealed a lower incidence frequency of plasminogen activator inhibitor PAI-1 5G/5G in the main group compared to control $(\mathrm{p} \leq 0.001)$, and a higher frequency of PAI-1 5G/4G+ PAI-1 4G/4G in the main group ( $\mathrm{p} \leq 0.001$ and $\mathrm{p} \leq 0.001$ respectively);

- homozygous carrier integrin alpha 2- ITGA2 807 (C>T) T/T was reliably more common in the main group relative to control $(\mathrm{p} \leq 0.002)$ (table 2$)$.

Table 2. Comparative study of frequencies of enzymes genes polymorphisms of plasma, platelet, fibrinolytic links of hemostasis system in observation groups

\begin{tabular}{|l|c|c|c|c|c|}
\hline \multirow{2}{*}{ Polymorphism } & \multicolumn{2}{|c|}{ Main group, $\mathrm{n}=463$} & \multicolumn{2}{c|}{ Control group, $\mathrm{n}=57$} & $\begin{array}{c}\mathrm{p}\left(\chi^{2}\right) \\
\leq\end{array}$ \\
\cline { 2 - 6 } & $\mathrm{n}$ & $\%$ & $\mathrm{n}$ & $\%$ & \\
\hline F1: FGB -455 G/G & 27 & 58.7 & 48 & 84.8 & $\mathbf{0 . 0 0 4}$ \\
F1: FGB -455 G/A & 15 & 32.6 & 8 & 13.4 & $\mathbf{0 . 0 2 5}$ \\
F1: FGB -455 A/A & 4 & 8.7 & 1 & 1.75 & 0.104 \\
F1:G/A+A/A & 19 & 41.3 & 9 & 15.7 & $\mathbf{0 . 0 0 4}$ \\
\hline
\end{tabular}




\begin{tabular}{|c|c|c|c|c|c|}
\hline $\begin{array}{l}\text { F2: } 20210 \mathrm{G} / \mathrm{G} \\
\text { F2: } 20210 \mathrm{G} / \mathrm{A} \\
\text { F2: } 20210 \mathrm{~A} / \mathrm{A} \\
\text { F2: } 20210 \mathrm{G} / \mathrm{A}+\mathrm{A} / \mathrm{A}\end{array}$ & $\begin{array}{c}42 \\
4 \\
- \\
4\end{array}$ & $\begin{array}{c}91.3 \\
8.7 \\
- \\
8.7\end{array}$ & $\begin{array}{c}56 \\
1 \\
- \\
1\end{array}$ & $\begin{array}{c}98.25 \\
1.75 \\
- \\
1.75\end{array}$ & $\begin{array}{c}0.104 \\
0.104 \\
- \\
0.104\end{array}$ \\
\hline $\begin{array}{l}\text { F5: Leiden } 1691 \mathrm{G} / \mathrm{G} \\
\text { F5: Leiden } 1691 \mathrm{G} / \mathrm{A} \\
\text { F5: Leiden } 1691 \mathrm{~A} / \mathrm{A} \\
\text { F5: Leiden } 1691 \mathrm{G} / \mathrm{A}+ \\
\text { A/A }\end{array}$ & $\begin{array}{l}46 \\
- \\
- \\
-\end{array}$ & $\begin{array}{c}100 \\
- \\
- \\
-\end{array}$ & $\begin{array}{l}57 \\
- \\
- \\
-\end{array}$ & $\begin{array}{c}100 \\
- \\
- \\
-\end{array}$ & $\begin{array}{l}- \\
- \\
- \\
-\end{array}$ \\
\hline $\begin{array}{l}\text { PAI-1-675 5G/5G } \\
\text { PAI-1-675 5G/4G } \\
\text { PAI-1 -675 4G/4G } \\
\text { PAI-1 -675 } \\
5 \mathrm{G} / 4 \mathrm{G}+4 \mathrm{G} / 4 \mathrm{G}\end{array}$ & $\begin{array}{c}9 \\
18 \\
19 \\
37\end{array}$ & $\begin{array}{l}19.5 \\
39.2 \\
41.3 \\
80.4\end{array}$ & $\begin{array}{c}33 \\
20 \\
4 \\
24\end{array}$ & $\begin{array}{c}57.1 \\
35.7 \\
7.2 \\
42.1\end{array}$ & $\begin{array}{l}\mathbf{0 . 0 0 1} \\
0.673 \\
\mathbf{0 . 0 0 1} \\
\mathbf{0 . 0 0 1}\end{array}$ \\
\hline $\begin{array}{l}\text { FactorVII G10976A G/G } \\
\text { FactorVII G10976A G/A } \\
\text { FactorVII G10976A A/A } \\
\text { FactorVII G10976A } \\
\text { G/A+ A/A }\end{array}$ & $\begin{array}{c}40 \\
6 \\
- \\
6\end{array}$ & $\begin{array}{c}87 \\
13 \\
- \\
13\end{array}$ & $\begin{array}{c}53 \\
4 \\
- \\
4\end{array}$ & $\begin{array}{c}92.8 \\
7.2 \\
- \\
7.2\end{array}$ & $\begin{array}{l}0.305 \\
0.305 \\
\\
0.305\end{array}$ \\
\hline $\begin{array}{l}\text { Factor XIII Val34Leu } \\
\text { G/G } \\
\text { Factor XIII Val34Leu } \\
\text { G/T } \\
\text { Factor XIII Val34Leu T/T } \\
\text { Factor XIII Val34Leu } \\
\text { G/T+ T/T }\end{array}$ & $\begin{array}{c}30 \\
16 \\
- \\
16\end{array}$ & $\begin{array}{c}65.2 \\
34.8 \\
- \\
34.8\end{array}$ & $\begin{array}{c}41 \\
16 \\
- \\
16\end{array}$ & $\begin{array}{c}71.4 \\
28.6 \\
- \\
28.6\end{array}$ & $\begin{array}{l}0.465 \\
0.465 \\
- \\
0.465\end{array}$ \\
\hline $\begin{array}{l}\text { ITGA2 } 807 \mathrm{C} / \mathrm{C} \\
\text { ITGA2 } 807 \mathrm{C} / \mathrm{T} \\
\text { ITGA2 } 807 \mathrm{~T} / \mathrm{T} \\
\text { ITGA2 } 807 \mathrm{C} / \mathrm{T}+\mathrm{T} / \mathrm{T}\end{array}$ & $\begin{array}{l}21 \\
15 \\
10 \\
25\end{array}$ & $\begin{array}{l}45.6 \\
32.6 \\
21.8 \\
54.3\end{array}$ & $\begin{array}{c}32 \\
24 \\
1 \\
25\end{array}$ & $\begin{array}{l}56.1 \\
42.2 \\
1.75 \\
43.8\end{array}$ & $\begin{array}{l}0.290 \\
0.324 \\
\mathbf{0 . 0 0 2} \\
0.290\end{array}$ \\
\hline $\begin{array}{ll}\text { ITGB3 } & 1565 \mathrm{~T} / \mathrm{T} \\
\text { ITGB3 } & 1565 \mathrm{~T} / \mathrm{C} \\
\text { ITGB3 } & 1565 \mathrm{C} / \mathrm{C} \\
\text { ITGB3 } & 1565 \mathrm{~T} / \mathrm{C}+\mathrm{C} / \mathrm{C}\end{array}$ & $\begin{array}{c}30 \\
14 \\
2 \\
16\end{array}$ & $\begin{array}{c}65.2 \\
30.4 \\
4.4 \\
34.8\end{array}$ & $\begin{array}{c}41 \\
16 \\
0 \\
16\end{array}$ & $\begin{array}{c}72 \\
28 \\
0 \\
28\end{array}$ & $\begin{array}{l}0.465 \\
0.056 \\
0.112 \\
0.465\end{array}$ \\
\hline
\end{tabular}

Analysis of associative indicators in order to assess the contribution of PAI-1 4G allele and gene-gene combinations to the clinical implementation of arterial and venous thrombosis in newborn children showed that the presence of $4 \mathrm{G}$ allele in the gene PAI-1 675 increases the attributive risk of thrombosis in newborns by $39 \%, \mathrm{p} \leq 0.001$; increases the likelihood of thrombosis by 5.6 times (OR=5.6 [2.3-13.8]). The 4G allele of PAI-1 -675 polymorphism has been shown to have strong causal significance in the realization of thrombosis, as evidenced by high attributive or etiological fraction- $64 \%$. The presence of a $5 \mathrm{G}$ allele in heterozygous carrier reduces the risk of thrombosis development.

It was found that the presence of PAI-1 $-6754 \mathrm{G} / 4 \mathrm{G}$ polymorphism increased the attributive risk of thrombosis development in newborns by $48.8 \%, \mathrm{p} \leq 0.001$; increases the probability of thrombosis development by 9 times ( $\mathrm{OR}=9.3$ [2,8-30.1]).

It was found that the presence of ITGA2 $807 \mathrm{~T} / \mathrm{T}$ polymorphism increased the attributive risk of thrombosis development in newborns by $52 \%, \mathrm{p} \leq 0.002$; increases the probability of thrombosis development by 15 times (OR=15.56 [1,9-126.7]). ITGA2 807 $\mathrm{T} / \mathrm{T}$ polymorphism has been shown to have strong causal significance in the 
implementation of thrombosis, as evidenced by high attributive or etiological fraction $57 \%$.

Heterozygous and homozygous carrying sum of fibrinogen polymorphisms FGB-455 (G>A) G/A+FGB-455 (G>A) A/A increased the attributive risk of thrombosis development by $32 \%, p \leq 0.004$ and increased the probability of thrombosis development by almost 4 times $(\mathrm{OR}=3.75$ [1.4-9.4]). The etiological contribution of allele A of polymorphism FGB455 is $44 \%$ in the development of arterial and venous thrombosis in newborn children (Table 3).

Table 3. Risk of thrombosis development depending on the genetic variant of plasma, platelet and fibrinolytic hemostasis genes in newborn children

\begin{tabular}{|c|c|c|c|c|c|c|}
\hline Genetic variant & $\begin{array}{c}\text { Thrombose } \\
\text { s, } \\
\mathrm{n}(\%)\end{array}$ & $\begin{array}{l}\text { AR,\% } \\
95 \% \mathrm{DI}\end{array}$ & $\mathrm{p} \leq\left(\mu^{2}\right)$ & $\begin{array}{c}\mathrm{RR} \\
95 \% \mathrm{DI}\end{array}$ & $\begin{array}{c}\text { OR } \\
95 \% \mathrm{DI}\end{array}$ & $\% \mathrm{AR}$ \\
\hline \multicolumn{7}{|c|}{ Allel } \\
\hline $\begin{array}{l}\text { PAI-1 «- } 675 \text { 4G» }(+), n=61 \\
\text { PAI-1 «- } 675 \text { 4G» }(-), n=42\end{array}$ & $\begin{array}{l}37(61) \\
9(21)\end{array}$ & 39.2 & 0.001 & $\begin{array}{c}2.8 \\
1.5-5.2\end{array}$ & $\begin{array}{c}5.6 \\
2.3-13.8\end{array}$ & 64 \\
\hline \multicolumn{7}{|c|}{ Genotypes } \\
\hline $\begin{array}{l}\text { PAI-1 «-675 4G/4G» }(+), n=23 \\
\text { PAI-1 «-675 4G/4G» }(-), n=80\end{array}$ & $\begin{array}{l}19(83) \\
4(34)\end{array}$ & 48.8 & 0.001 & $\begin{array}{c}2.4 \\
1.7-3.5\end{array}$ & $\begin{array}{c}9.32 \\
2.8-30.1\end{array}$ & 58 \\
\hline $\begin{array}{l}\text { Factor I “- } 455 \mathrm{G} / \mathrm{A}+\mathrm{A} / \mathrm{A} \text { ” (+), } \\
\mathrm{n}=28 \\
\text { Factor I “-455 G/A+ A/A” (-), } \\
\mathrm{n}=75\end{array}$ & $\begin{array}{l}19(68) \\
27(36)\end{array}$ & 31.8 & 0.004 & $\begin{array}{c}1.8 \\
1.2-2.7\end{array}$ & $\begin{array}{c}3.75 \\
1.4-9.4\end{array}$ & 44 \\
\hline $\begin{array}{l}\text { ITGA2 } 807 \mathrm{~T} / \mathrm{T}(+), \mathrm{n}=11 \\
\text { ITGA2 } 807 \mathrm{~T} / \mathrm{T}(-), \mathrm{n}=92\end{array}$ & $\begin{array}{c}10(91) \\
36(39.1)\end{array}$ & 51.8 & $\begin{array}{l}10.65 \\
0.002\end{array}$ & $\begin{array}{c}2.32 \\
1.6-3.1\end{array}$ & $\begin{array}{c}15.56 \\
1.9-126.7\end{array}$ & 57 \\
\hline
\end{tabular}

The plasminogen activator inhibitor affects fibrinolysis and prevents clots from dissolving, which increases the risk of vascular complications of various thromboembolisms. Also, when assessing the risk of arterial and venous thrombosis, attention is paid to genes of blood coagulation factors - Factor VII and Factor XIII, changes in which in most cases are directed to providing a protective effect. Reduced activity of these factors contributes to reduced thrombogenesis. The combinations of plasminogen activator inhibitor genotypes and Factor VII, plasminogen activator inhibitor and Factor VII and Factor XIII were considered in terms of risk assessment and etiological contribution of these combinations in the thrombogenesis development.

The PAI-1 -675 4G/4G + factor VII G10976A G/G combination was found to also increase the attributive risk by $40 \%(\mathrm{p} \leq 0.002)$ and the probability of thrombosis development by almost 6 times (OR=5.8 [1.7-19.1]). The etiological contribution to the development of arterial and venous thrombosis in newborns of this combination was $50 \%$. This means that among children with this combination of genotypes $50 \%$ of thrombosis development cases were separately connected to the presence of a given combination.

The combination of PAI-1 -675 4G/4G + factor VII G10976A G/G + factor XIII Val34Leu G/G polymorphisms increased the attributive risk of thrombosis by $39 \%$, $\mathrm{p} \leq 0.001$. The etiological contribution to the development of arterial and venous thrombosis in newborns of this combination was $60 \%$. This means that among children with this 
combination of genotypes, $60 \%$ of thrombosis development cases were isolated to the presence of this combination.

Table 4. Risk of thrombosis development depending on genotype combinations in newborns

\begin{tabular}{|c|c|c|c|c|c|c|}
\hline Genetic variant & $\begin{array}{c}\text { Thromboses, } \\
\text { n (\%) }\end{array}$ & $\begin{array}{l}\text { AR, } \% \\
95 \% \text { DI }\end{array}$ & $\mathrm{p} \leq\left(\mu^{2}\right)$ & $\begin{array}{c}\mathrm{RR} \\
95 \% \mathrm{DI}\end{array}$ & $\begin{array}{c}\text { OR } \\
95 \% \mathrm{DI}\end{array}$ & $\% \mathrm{AR}$ \\
\hline \multicolumn{7}{|c|}{ Combinations of 2 genotypes } \\
\hline $\begin{array}{l}\text { [PAI-1 “-675 4G/4G” / Factor } \\
\text { VII “G10976A G/G"] (+), n=18 } \\
\text { [PAI-1 “-675 4G/4G” / Factor } \\
\text { VII “G10976A G/G"] (-), n=85 }\end{array}$ & $\begin{array}{l}14(78) \\
32(38)\end{array}$ & 40.1 & 0.002 & $\begin{array}{c}2.0 \\
1.4-2.98\end{array}$ & $\begin{array}{c}5.79 \\
1.7-19.1\end{array}$ & 50 \\
\hline \multicolumn{7}{|c|}{ Combinations of 3 genotypes } \\
\hline $\begin{array}{l}\text { [PAI-1 “-675 4G/4G" / } \\
\text { FactorVII "G10976A G/G" / } \\
\text { Factor XIII "Val34Leu G/G"] } \\
\text { (+), n=9 } \\
\text { [PAI-1 “-675 4G/4G" / FactorVII } \\
\text { "G10976A G/G" / Factor XIII } \\
\text { "Val34Leu G/G"] (-), n=94 }\end{array}$ & $9(100)$ & 60.7 & 0.001 & - & - & 61 \\
\hline
\end{tabular}

\section{Conclusion}

Genetic predictors of arterial and venous thrombosis development in the neonatal period include polymorphism of the plasminogen activator inhibitor gene PAI-1-675 4G/4G $(\mathrm{OR}=5.6$ [2.3-13.8]), polymorphisms combinations PAI-1-675 4G/4G + factor VII G10976A G/G (OR=5.8 [1.7-19.1]) polymorphisms combinations PAI-1-675 4G/4G + factor VII G10976A G/G + factor XIII Val34Leu G/G (\% AR=61), fibrinogen gene polymorphism FGB-455 G/A $(\mathrm{OR}=3.75[1,4-9.4])$ and polymorphism of the gene integrin alpha 2 ITGA2 $807 \mathrm{~T} / \mathrm{T}(\mathrm{OR}=15.56$ [1,9-126.7]). Identified predictors should be taken into account when assessing the individual risk of thrombogenesis in newborn children.

\section{References}

1. M. Andrew, M. David, M. Adams, et al., Venous thromboembolic complications (VTE) in children: first analyses of the Canadian Registry of VTE, Blood, 83, 1251-1257 (1994)

2. M. L. Avila, L. Duan, A. Cipolla, et al., Postthrombotic syndrome following upper extremity deep vein thrombosis in children, Blood, 124, 1166-1173 (2014)

3. U. Nowak-Gottl, C. Duering, B. Kempf-Bielack, R. Strater, Pathophysiol. Haemost. Thromb, 33, 269-274 (2003/2004)

4. L. Raffini, Y. S. Huang, C. Witmer, C. Feudtner, Pediatrics, 124, 1001-1008 (2009)

5. B. A. Setty, S. H. O'Brien, B. A. Kerlin, Pediatr. Blood Cancer, 59, 258-264 (2012)

6. H. Lawall, R. Oberacker, C. Zemmich, et al., BMC Res. Notes 7, 431 (2014)

7. B. A. Golomb, V. T. Chan, J. O. Denenberg, S. Koperski, M. H. Criqui, BMJ Open, 4, e003208 (2014)

8. U. Nowak-Göttl, R. Junker, W. Kreuz, et al., Blood, 97, 858-862 (2001)

9. N. A. Goldenberg, R. Knapp-Clevenger, M. J. Manco-Johnson, N. Engl. J. Med, 351, 1081-1088 (2004) 
10. Sofie Sommer Hedegaard, Anna Christina Klein \& Anne-Mette Hvas, Scandinavian Journal of Clinical and Laboratory Investigation, 551-555 (2018)

11. P. V. Svirin, S. A. Rumyantsev, L. E. Larina, A. V. Suvorova, A. P. Zharkov, Neonatology journal, 1, 76-84 (2013)

12. A. P. Momot, L. A. Strosenko, L. P. Tsyvkina, E. V. Roitman Methodological recommendations. Primary thromboprophylaxis in children of the Altai region on the basis of identification and modification of permanent and temporary factors of thrombogenic risk, Barnaul, 64 (2013)

13. V. S. Baranov, Genetic Passport - the basis of individual and predictive medicine, 528 (St. Petersburg, "N-L", 2009)

14. A. D. Makatsaria, V. O. Bitsadze, Thrombophilic conditions in obstetrical practice, 703 (M.: Russia. 2001)

15. E. V. Roitman, A. P. Momot, L. P. Tsyvkina, A. V. Fedorov, V. A. Yelykomov, P. V. Svirin, I. A. Olkhovsky, N. N. Kuznetsov, G. V. Serdyuk, U. A. Boyarskikh, M. L. Filippenko, V. A. Plyushkin, P. A. Zharkov, V. V. Shkryaburova, Y. F. Lobanov, Thrombosis, hemostasis and rheology, 3, 30-78 (2010)

16. G. Kenet, L. Lutkhoff, M. Albisetti, et al., Circulation, 121, 1838-1847 (2010)

17. G. Young, M. Albisetti, M. Bonduel, et al., Circulation, 118, 1373-1382 (2008)

18. I. A. Kelmanson, Fundamentals of Evidence-based Pediatrics, 240, 16 (M.: Russia, 2004) 